\title{
Learning and the School Library Resource Centre
}

\author{
Professor Dorothy Williams \\ Reader \\ d.williams@rgu.ac.uk \\ Caroline Wavell \\ Research Assistant \\ c.wavell@rgu.ac.uk \\ School of Information \& Media, \\ The Robert Gordon University, \\ Garthdee Road, \\ Aberdeen, $A B 107 Q E$, \\ United Kingdom
}

\begin{abstract}
School librarians are under increasing pressure to evaluate and justify their service provision in terms of benefits to the learner. The research project reported here examines the impact of the school library resource centre on learning. Using a range of focus groups, interviews and case studies, the work identified a range of potential indicators of learning which provide a useful starting point for librarians to begin examining activities in relation to the learner. The study was conducted in Scottish secondary schools between August 1999 and February 2001 and complements empirical work carried out in other countries. All these studies were the subject of a critical review of literature recently completed by the research team. The paper discusses some of the major themes that emerge from the empirical study and were reflected in other studies; such as the impact the library has on formal academic attainment and informal personal achievements, factors that limit the learning and how this relates to the type of library provision in terms of resources and professional expertise.
\end{abstract}

\section{Context}

This paper reports the context, methodology and empirical findings of a research project which examined the impact of the school library resource centre (SLRC) on learning. The aim of this two-phase study was to identify what teachers, pupils and school librarians perceived to be the impact of the SLRC on learning and then to use a framework of perceived learning benefits (developed from the first phase) to examine the actual learning experience, and identify indicators to be used as evidence of learning. The study in Scottish secondary schools was conducted by researchers at the Robert Gordon University between August 1999 and February 2001 and was funded by Resource: The Council for Museums, Archives and Libraries. More recently, work has been completed on a review of literature from the English speaking world to inform Resource and the UK government Department of Education and Skills (DfES) of the evidence which exists on the impact of school libraries on achievement in learning (Williams, Wavell \& Coles, 2001 and Williams, Coles \& Wavell, 2002). Much of this literature has been widely publicised and, together with our empirical findings, provides a useful pool of knowledge to promote further developments within the profession. 
The Impact of the SLRC on Learning project was undertaken at a time of increasing pressure world-wide to measure performance in educational and publicly funded establishments, including libraries and information services. In the U.K. a number of government initiatives meant that this research was particularly timely. The National Grid for Learning (NGfL) and the implementation of information and communication technology (ICT) networks within schools has been the subject of major capital investment since the late nineties, giving rise to further interest in monitoring and independent evaluation. This technology drive provided opportunities for school libraries to become instrumental in implementing and supporting new formats of information delivery. At the same time the government introduced curriculum developments within the Scottish and English education systems to encourage higher educational standards and the nation-wide campaign for Lifelong Learning within and beyond formal education. Again this has provided libraries and information services with renewed focus and a higher profile.

At the time of the research both Scottish and English schools were pursuing the management led issue of quality assurance and benchmarking. In Scotland, the use of performance indicators to self-evaluate the quality of educational provision in school (HMI Audit Unit, 1996) has been paralleled by education and library organisations' attempts to develop guidelines (CoSLA, 1999) and indicators for evaluating the school library resource centre (SOEID, et.al., 1999) within the context of the school as a whole. One key area identified for evaluation is that of Learning and Teaching. However, the task of establishing the contribution of the SLRC to the quality of learning within the school requires an understanding of the relationship between the library-based activities and the learning goals of the curriculum and the school as a whole. From the early days of the research it was clear that this was area of potential challenge for librarians and teachers alike.

Traditional attempts to measure performance in relation to library and information services focus on the measure of outputs, in terms of expenditure, resource provision and levels of library use. This approach may ensure efficiency of service but does little to enhance professional understanding of effectiveness of the service provided and how this can be improved. Evaluation of the impact of the SLRC on learning requires a focus on outcomes associated with the learning experience and achievement. In schools this shift in emphasis has posed a number of challenges for the information and library profession as well as the teaching profession. There are significant questions to asked about the role of the SLRC in relation to effective learning and the means of capturing data which may be qualitative in nature and may not be readily available at the point of service provision. It was hoped that the research would help provide the basis of a practical approach which schools could use as part of their own ongoing evaluation and improvement of the impact of the SLRC on learning.

There is a growing body of research both in the UK and elsewhere which attempts to examine the impact of information and library services in terms of outcomes. Some have considered the impact of information use on decision-making (Marshall, 1992 and Urquahart, 1995) and such research provided valuable points of reference (and contrast) when developing appropriate methods for the study in Scottish schools. Evidence relating to the impact of the school library has emerged from a variety of studies over recent years. The international literacy study conducted by Elley $(1992,1994)$ and Krashen's work in the US (1993) examine the relationship between reading development and book provision and use and conclude that the school library has an important role in supporting literacy. In the USA studies have begun to look more closely at the relationship between learning and school library provision. The statistical studies conducted by Keith Lance (Lance, et.al., 1993, 
2000a, b, c,) and those following his model (Hall-Ellis, 1995, Baughman, 2000, and Smith, 2001) provide compelling evidence of a correlation between school library provision and learning, particularly in the earlier educational years. However, the qualitative studies conducted as part of the Library Power programme (Hopkins \& Zweizig, 1999 and Zweizig \& Hopkins, 1999) and the research presented here (Williams \& Wavell, 2001) explore in more depth the relationship between aspects of provision and the type of learning experience.

In formal education emphasis is placed on academic achievement. The quantitative studies following the Lance model, which demonstrate a statistical correlation between school library provision and achievement in standard attainment tests, are particularly useful in demonstrating the overall impact of the school library in terms which will be understood by policy and decision makers. However, there is potential for more extensive investigation of the broader aspects of learning particularly in relation to libraries and the development of attitudes and skills which will equip students for lifelong learning. In the UK, research is beginning to look at how institutions for informal learning, for example public libraries, museums and galleries, can contribute to student achievement and learning (Train, B. et.al. 2000; Sharp, C. et.al. 2001; and London's Transport Museum, 2001). Schools too are concerned with the broader aspects of learning and for this reason our impact study adopted a broad definition of learning encapsulating the positive attitude necessary to accept learning and develop it further:

"Learning is a process of active engagement with experience. It is what people do when they want to make sense of the world. It may involve an increase in skills, knowledge, understanding, values and the capacity to reflect. Effective learning leads to change, development and a desire to learn more. " (Campaign for Learning, 2001)

\section{Methodology}

The impact study was set in the context of the Scottish educational system in which professionally qualified librarians, and in some cases with a library assistant, staff secondary school library resource centres. Secondary schools interested in taking part were invited to complete a questionnaire designed to establish whether they were addressing the standards set out by CoSLA (1999) for school library provision. The criteria for the final selection of schools were based on the enthusiasm and commitment of the school and librarian to the project. The first phase of the study used separate focus group discussions with teachers and pupils and interviews with librarians in ten schools to identify their perceptions of how the SLRC can contribute to learning. The second phase used case studies of a range of learning activities associated with the SLRC in six of those ten schools. The case units aimed to establish whether this perceived impact on learning was indeed taking place; identify indicators which might be used as evidence of learning; and examine the process of assessing the impact of the SLRC on learning. For this study learning was considered in its broadest sense and included motivation, progression, independence, and interaction.

The focus groups and interviews provided a wealth of information on SLRC use, on what the various groups perceived the SLRC contributes to learning and what factors were thought to influence the effectiveness of the learning process. For some participants this discussion on the school library and learning provided a rare opportunity for reflection. As expected however, the participants found it difficult to identify specific indicators of learning in the SLRC context as opposed to the more formal and stipulated curriculum outcomes. The quality of the discussion varied and was dependent upon numbers and key participants within 
the groups and also reflected the status of the school library within senior management agenda.

Detailed notes of the taped discussions were analysed manually and emergent key themes were considered against established educational theory, such as Bloom (1956) and Scottish curriculum guidelines (SCCC, 1999). Although some interesting comparisons could be made between different subject departments or even schools, this was not focus of the study and will not be discussed in this paper. The focus group discussions taken as a whole provided data to develop a framework of perceived learning experiences associated with the SLRC. These were categorised under the headings of motivation, progression, independence, and interaction, reflecting the themes used in current guidelines for evaluating school (and library) performance in relation to 'Quality of pupils' learning' (SOEID, et.al, 1999) and provide a basis for examining learning in its broader context. These themes also reflect categories of learning identified in other educational literature, such as the Scottish secondary curriculum guidelines which stress skills, knowledge \& understanding and developing informed attitudes (SCCC, 1999) as well as Bloom's affective, psychomotor, lower and higher cognitive categories (Bloom,1956).

An initial range of potential indicators of impact were developed from these learning experiences and were used during the case studies to take a broad look at the learning associated with the SLRC. Analysis of the focus group data also identified a range of conditioning factors which were thought to impact on the quality of learning and these reflected difficulties experienced by teachers, pupils and librarians, such as time, environmental and financial constraints, and the personality and experiences of the individuals involved. These factors were not generally within the direct control of individual teachers or librarians.

The second phase of the research examined a selection of library-based activities across a broad spectrum of year groups and subject areas, each activity taken as an individual case study. These included student research projects, student librarians and reading promotion as detailed below:

1. English project in which students in the first year of secondary education (S1, aged 12-

13) investigated an animal for a piece of functional (factual) writing.

2. Modern language co-operative learning project, with first year secondary students (S1), finding out about various aspects of French culture in small groups, reporting to another group and joining forces to put the collective information together for a further presentation to the whole class.

3. Project using theoretical geography taught in the classroom to second year (S2) students who then gathered information in the library to produce a booklet on natural disasters.

4. A Higher (advanced examination for post 16 year students) level biology investigation requiring background information to support an experimental project of the student's choice for submission to the examination board.

5. Skills course designed to refresh third year (S3) students in the use of library resources and to give practice in study skills, particularly time management, while producing a piece of factual writing on an aspect of healthy living.

6. S1 students reading for pleasure using a variety of methods promoted by the librarian to stimulate interest in a variety of literature genres.

7. Volunteer student librarians (S2-S5) and informal learning through working in and promotion of library duties.

8. Ad hoc use of the library and special events promoted by the library were observed to consider the learning opportunities and the challenges posed for gathering impact data. 
A suite of data collection methods and sources (students, teachers, librarians) were used in each case study to ensure triangulation: evidence was collected by means of observation, discussion or questioning, examination of work in progress and finished work, and evidence beyond the immediate situation. The data collection techniques were adapted and refined for each case study, reflecting both the local circumstances and lessons learnt from previous cases. No one method proved ideal and all required care and time for preparation and evaluation and more details of these are available in the full report (Williams \& Wavell, 2001).

The research team had intended to discuss the indicators of impact and methods of data collection with the teachers and librarians involved in each case unit to encourage local participation and involvement in the research process. However, this proved less easy in practice. The participants engaged with the research in varying degrees but none were fully confident to 'own' the research and develop it locally. This resulted in a shift in emphasis in the case study approach. Instead of the participating teachers and librarians selecting indicators they felt appropriate for their local circumstances and using those indicators to gather evidence of actual impact, the research team took a more investigative approach to the study. The researchers used the initial framework of possible indicators of impact to establish the nature of the learning which was taking place and how this related to the expected curriculum outcomes.

\section{Research Outcomes: Indicators, Methods for Collecting Evidence}

The case studies were successful in establishing a range of learning experiences that the SLRC has the potential to impact upon as well as factors that need to be taken into consideration when planning effective learning. Figure 1 gives examples of some indicators of impact that were used to identify learning within the school library context.

Figure 1

Examples of Possible Indicators of Impact of SLRC on Learning

\begin{tabular}{|c|c|c|c|}
\hline MOTIVATION & PROGRESSION & INDEPENDENCE & INTERACTION \\
\hline $\begin{array}{l}\text { - } \begin{array}{l}\text { Expression of } \\
\text { enthusiasm }\end{array} \\
\text { - Absorption in } \\
\text { task } \\
\text { - Continuation of } \\
\text { task } \\
\text { - Change in } \\
\text { attitude }\end{array}$ & $\begin{array}{l}\text { - } \begin{array}{l}\text { Use of relevant } \\
\text { information }\end{array} \\
\text { - } \text { Find appropriate } \\
\text { information on } \\
\text { Internet } \\
\text { - Use of catalogue } \\
\text { - Evidence of new } \\
\text { knowledge } \\
\text { Higher personal } \\
\text { achievement } \\
\text { Reading different } \\
\text { fiction genres }\end{array}$ & $\begin{array}{l}\text { Confidence \& } \\
\text { competence to } \\
\text { continue unaided } \\
\text { Awareness of } \\
\text { need for help and } \\
\text { confidence to } \\
\text { seek help } \\
\text { Ability to apply } \\
\text { or transfer skills } \\
\text { to new context } \\
\text { Increased self- } \\
\text { esteem } \\
\text { Use of initiative }\end{array}$ & $\begin{array}{l}\text { - Discussion about } \\
\text { task } \\
\text { - Peer co- } \\
\text { operation } \\
\text { - Friendships } \\
\text { - Use of } \\
\text { appropriate } \\
\text { behaviour }\end{array}$ \\
\hline
\end{tabular}

These indicators of learning are not specific to the school library environment and, at this stage, only serve to explain the range of potential learning associated with the school library. Several of the indicators identified during this impact study were also identified by Kuhlthau during the Library Power evaluation study (Kuhlthau, 1999) and taken with evidence of impact from other studies examined in recent critical literature reviews 
(Williams, Coles \& Wavell, 2002 and Williams, Wavell \& Coles, 2001) these indicators have the potential to provide a useful mechanism for librarians to start looking at learning in greater depth. The application of such indicators in the impact study enabled learning to be observed in a broader context than the more traditional focus on the development and application of information skills. Thus, the library was observed to be a motivating force for some students, particularly when computers were involved, and the environment was also observed to provide students with opportunities to develop social and interpersonal skills. Use of the library enabled progression in the learning task by encouraging the development of research and ICT skills: for some students proficiency in aspects of information literacy enabled them to demonstrate independence.

However, there is a complex inter-relationship between all these aspects of learning and this needs to be taken into account when planning and evaluating impact on learning. For example, motivation was identified in the impact research as an important factor in enabling students to progress with specific tasks. Interestingly, while many teachers in the focus groups had indicated that they considered the library to be in itself a motivating influence, it was clear in many cases that this was not enough to encourage real progression in the task and that there was a need for specific strategies to maintain motivation. Small (1998 \& 1999) has identified strategies to help motivate students in the SLRC but observation of the case studies suggests that planning for motivation is not always given due consideration in the implementation of activities.

Independence in learning is dependent upon progression, upon students' ability and confidence to proceed unaided. Again it was observed that timely intervention was not necessarily available to ensure students could overcome minor obstacles in order to progress with confidence. Progression and interaction help motivation and interaction is important for some students to progress as well as providing a useful means of demonstrating that progression. In other words, the focusing on a wider range of indicators than the more usual focus on information skills and task achievement, it is possible to gain a deeper understanding of the complexity of the impact of the SLRC on learning. However, such an approach is potentially more challenging in terms of data collection.

The challenges of evaluating impact are acknowledged from other studies looking at the impact of information on the business and professional contexts (Marshall, 1993 and Urquhart, 1995). It is also recognised that valid indicators of impact and the means of monitoring them should reflect the local environment. One of the objectives of this research was to examine how impact might be measured in the school library context and the practicalities associated with various methods. While a range of traditional techniques were used during this study; i.e. discussions, questionnaires, self-evaluation, diaries, observation and examination of written work, some of these methods proved more useful and/or practical than others. Observation provided a valuable opportunity to assess what was happening in the class situation especially when the findings are carefully considered with evidence of previous experience and subsequent written work. However it is recognised that this is impractical on a regular basis when librarians and teachers are occupied with a number of activities during the same session in the SLRC. On the other hand, it was observed during the case studies that teachers and librarians do not make the most of opportunities to discuss observations at the time or reflect on the activities in any detail. In order to make the most of any observation time it is important to have the aims and objectives of the activity clearly identified so that observation and reflection is focused. During one of the case studies an observation schedule was used to give more accurate quantitative measurement and this was 
thought to provide a useful basis for a checklist to assess how individuals are coping with itemised tasks, such as library skills.

Open-ended questioning of students using a simple evaluation sheet provided useful feedback both for evidence of immediate impact and for difficulties encountered to enable improvements for future activities. The most successful questions were those asking what was learned, what was enjoyed, what difficulties were encountered. Discussion during the sessions provided useful spontaneous evidence of motivation but also enabled skills, knowledge and understanding to be established at the point of use allowing for appropriate intervention to aid progression.

The use of diaries and critical incident techniques were not as successful in this study as in other research where they have been used (Kuhlthau, 1993 and Marshall, 1993). The reasons for this were not fully identified but certainly the inability of some of participants to grasp the concept of learning in an abstract way may have accounted for some of the problems.

As might be expected some elements of learning are easier to monitor than others. For instance it was easier to examine the immediate learning context, i.e. the work done within the library, rather than the longer-term outcomes. Indicators for progression can be very specific and relatively easily managed within the SLRC context and useful feedback can be gained from being able to discuss progress in relation to curriculum aims and objectives with teachers involved with the activity in the SLRC. However, the use of the library impacts on learning beyond the immediate setting and the study suggested that it is important for librarians and teachers to be aware of the need to take a long-term approach to monitoring impact, examining preceding work and changes occurring after participation in the library activity. For example, in normal circumstances students' completed work is often not available for the librarian to examine, yet in this study useful evidence was gained from examining the "end products" in relation to the work which had been undertaken in the SLRC.

It was also found to be useful to consider looking for evidence of indirect impact beyond the immediate learning activity but again this would be most useful when clear aims and objectives have been identified for a particular activity, such as changes in attitude of student librarians towards school work or improved interpersonal skills, and again specific indicators would need to be identified which express these changes.

The research provides the starting point for librarians and teachers to begin examining the learning experience within their own SLRC by providing a variety of techniques which could be used to monitor the impact on learning. The use of formative assessment and portfolio work is suggested by researchers in the US (Callison, 1993 and Kuhlthau, 1994) but little has been done in this area in the UK where there are no information literacy standards upon which to base such assessment. During the case studies it was observed that the work in progress and finished work did not always reflect the learning taking place in specific library aspects of the information handling process. 


\section{The Nature of the Learning Experience: Learning in Relation to Provision And Expertise}

The discussion of the learning experience begins with the evidence from the case studies that relates to student academic achievement. Implicit in the curriculum related case studies was the assumption that use of the SLRC would aid the development of research or information literacy skills. This type of library based activity is most closely identified with the 'progression' category of learning and as a consequence, would be expected to contribute to academic achievement. The appropriate use of information was an assumed aim for introducing the library element in research activities and yet this aspect of information literacy appeared to be the most challenging and least understood or recognised by the participating teachers and librarians. Although this was where the teachers and librarians placed the major emphasis within the curriculum related case studies this was not necessarily where the most effective learning was taking place.

It became apparent during the course of the case studies that students responded to the learning situation in three distinct ways:

- those who were not engaged with learning;

- those who engaged and used information; and

- those who engaged with the process of finding information.

In each case study there were a few students in both of the first two categories. One or two students in each class of twenty-five to thirty were observed to make no effort to find information, to seek help or instructions if unsure of what to do, produced no evidence of work in progress or failed to submit a completed project. These students were not necessarily picked up by the teacher and the reasons for their disaffection was not always apparent or explored, however, when questioned by the researcher these students expressed a lack of interest. A few more students in each case unit settled down to work independently and their work demonstrated an understanding of the processes involved in information handling; such as using a variety of resources, taking and checking notes. These students when tracked submitted finished work of a high standard. The majority of students were 'information finders' who were not really progressing beyond the stage of finding and reproducing information or demonstrating selectivity of resources which would reveal an understanding of the theoretical subject matter.

These 'information finders' were an interesting group because they provided evidence of where difficulties arose and pointers for future targeting of intervention. Some students encountered difficulties navigating particular resources: for example, one student was observed to find a CDROM but encountered difficulties navigating the software until his neighbour intervened. Another two students were observed to locate an appropriate encyclopaedia but had difficulty with alphabetical order and following up the instructions within the volume. Other students were expected to obtain information from a video but experienced difficulties trying to establish the best way to proceed. Another category of 'information finders' appeared to find appropriate information but then failed to use it: for example, several students located interesting details about their animals in case study one but this information was not included in their final work. Few of the geography and biology students demonstrated an understanding of how their theoretical knowledge of the subjects was linked to newly found information. The fact that teachers had not fully engaged with the impact study meant that it was difficult for the researchers to establish the nature of these omissions; whether students had made a deliberate decision to omit information located, 
whether they failed to interpret the relevance, or whether the information was just forgotten due to a lack of study management skills.

Students who encountered difficulties with the information process at critical learning points were identified as losing focus, developing coping strategies and finding accidental or unsought solutions to problems. This led to the identification of factors which appeared to inhibit (or conversely enhance) the learning experience, such as: a lack of motivation; a lack of the required skills and/or knowledge to proceed; a lack of confidence in ability and understanding to enable independent progression and a lack of timely intervention or interaction by the teacher, librarian or peers.

The factors identified as potentially inhibiting or enhancing the quality of learning during the focus group discussions centred on issues to do with management input issues of finance, time, environment. However, the factors observed to be inhibiting learning during the case studies were more directly related to the learning process and this was not necessarily recognised by the participating teachers and librarians. Throughout the case studies, students were observed to interact and show renewed interest when intervention was forthcoming from the teacher, librarian or peers, although one or two students were also observed not to respond positively to teacher intervention. Students were observed to struggle to establish focus at the beginning of sessions if they had not been given the opportunity to review and reflect on previous progress. Several students were observed to encounter difficulties when they failed to read or understand required instructions or concepts. The research identified critical learning points in each case study where timely intervention would have facilitated progression to the next stage of the task. Although the participating teachers and librarians mentioned use of the SLRC as providing opportunities for motivating students and encouraging interaction, this was not always followed up during the sessions and evaluated as part of the final discussions. The range of factors which influence the effectiveness of learning in the SLRC illustrates the need for careful planning and evaluation of library-based activities. However, to be effective there is a need for greater dialogue between teachers and the librarian; shared understanding of how the SLRC contributes to the whole learning picture; and more depth of understanding of the information handling process and how it relates to curriculum goals.

Other quantitative and qualitative studies investigating the impact of the library provision on academic achievement (Lance, et.al, 1993, 2000a,b.c; Smith, 2001; Zweizig \& Hopkins, 1999) suggest that academic standards are higher than in schools where the library has professional staff, is well stocked with a quantity and variety of quality materials and there is effective collaboration between the library and teaching staff. The selection of schools in the impact study ensured that these participating libraries were staffed by qualified librarians, that the stock was of a sufficient if not high standard and that library provision was valued by the school as contributing student learning. Yet, exploration of the learning environment and use of the indicators for progression and independence would suggest that essential factors were not necessarily present or effective in the library-learning equation. The identification of influencing factors goes some way in explaining the possible problems. Many of these related to collaboration (or lack of it) between the teacher and librarian and their mutual understanding of the aim, objectives and learning processes associated with library use. Taken together with evidence from other studies it would appear that this is an area at which to target further research and development. 
In the case studies concerned with wider learning issues - reading for enjoyment, volunteer librarians, special events and the pursuit of personal interests - the learning was often less tangible, less immediately apparent and less directly related to the formal acquisition of skills, knowledge and understanding, i.e. progression. The case study examining the library's role in promoting reading for pleasure provided clear evidence that students were encouraged to read more books and a wider variety through the planned interventions and support provided. This evidence was gathered through open and closed questionnaire responses and was also clear in the increased interest in the award system developed by the librarian. Limited exploration of the library management system also indicated that students were influenced in their borrowing habits by discussion of books either during library sessions or informally between peers. The nature of the case study and lack of teacher involvement did not allow for fuller examination of formal reading and writing development or progression in this case.

The idea of ad hoc use of the library for personal interests and librarian involvement in special events - in this case hosting visiting authors, a space fair and a Times Education Supplement Newspaper Day - is to motivate and stimulate student interests beyond formal education. The scope of this research could not provide substantial evidence of impact because the methodology was designed as exploratory. However, there was limited evidence that events such as these can impact on individual students in subtle ways which might easily go undetected because the evidence lies outside the context of the library. For instance, one student talked to a visiting author about entering a story for a literary competition, another student enquired about joining the local astronomical society after the space fair, and yet another indicated to the researcher that he would like to use his experience of writing the newspaper to enter a career of journalism. These are small indicators of impact and this research has only begun the process of trying to establish methodologies and techniques for monitoring the impact of such ad hoc use of the SLRC.

The student librarians were given the opportunity to describe their learning experience in diary format as well as through informal discussions with the researcher. They all found it difficult to express what they did in terms of learning but observation during their duty sessions and limited observation and discussion of how this interacted with lessons provided useful insights into significant contributions to learning. The librarian in this case study school gave volunteer librarians a great degree of freedom and responsibility to develop their own ideas and duties. This provided numerous opportunities for the acquisition of new skills, particularly ICT, and in turn the confidence and ability to share that knowledge with other users. This was particularly apparent when some of the second year student librarians were involved with class research projects requiring a Power Point presentation. When guidance teachers were approached for insights into changes in attitude and self-esteem in these students, most were cautious in their responses. However, two teachers commented on an improved attitude towards school in general and increased self-esteem in one particular student since his involvement with the SLRC. This case study and the action research carried out by Dyer (2001) would suggest that if the involvement of student librarians is carefully considered, planned and monitored that substantial contributions can be made to both the development of skills and the less tangible affective and interpersonal aspects of learning.

These case studies suggested a substantial amount of informal learning was taking place within the context of the library but that this is often overlooked or not given significant consideration. The literature reviews identified a number of other specific studies (Balaam, 1997, Dyer, 2001, Hopkins, 1989, McNicol, 1999, Murrary, 2000 and Small, 1998 \& 1999) 
which contribute to our understanding of the impact of the library in these wider aspects of learning.

\section{Conclusion}

The research project provides a timely examination of some of the issues facing school librarians in their need to investigate at a local level the impact their services have on student learning. The findings of this study contribute to the accumulating evidence that the school library can contribute a great deal to both formal and informal learning given appropriate understanding and intervention. The large quantitative studies conducted in Colorado or Texas (Lance, et.al.1993, 2000a,b,c and Smith, 2001) examine academic achievement in relation to the school library resource centre; the IEA international studies (Elley, 1992, 1994) investigated reading development and suggest the importance of resource provision for school aged students; the large scale qualitative studies (Hopkins \& Zweizig, 1999 and Zweizig \& Hopkins, 1999) supported by the Information Power standards (AASL \& AECT, 1998) consider a number of aspects of school library use and incidentally the impact this has on learning; or small scale action research projects which look at specific aspects of learning such as Murray's (2000) investigation of students with disabilities. The potential learning experiences and indicators of impact provide one way to take the evidence further by inviting librarians and teachers themselves to use and adapt them for their own particular situation.

The study also confirms many of the challenges already identified when attempting to integrate two areas of professional expertise without a real dialogue or common understanding of the issues involved. Many of the issues that were identified during the impact of the SLRC on learning project will already be well recognised within the international field of school librarianship. The study confirms the importance of teacherlibrarian collaboration based on shared educational and learning goals but has perhaps added to our understanding of the complex impact which such collaboration (or lack of it) can have on the learner's experience.

\section{References}

American Association of School Librarians \& Association of Educational Communications and Technology. (1998). Information Power: building partnerships for learning. Chicago: American Library Association.

Baughman, J.C. \& Eldringhoff, M.S. (1999). Massachusetts School Library Media Survey. http://artemis.simmons.edu/ baughman/survey/ [22/02/02]

Bloom, B.S. (1956). Taxonomy of Educational Objectives. Vols 1 \& 2. London: Longmans, Green \& Co Ltd.

Callison, D. (1993). The Potential for Portfolio Assessment. School Library Media Annual (SLMA), 11, 30-39.

Campaign for Learning Home Page. http://www.campaign-for-learning.org.uk/ [11-01] 
CoSLA. (1999). Standards for School Library Resource Services in Scotland: a framework for developing services. Convention of Scottish Local Authorities.

Elley, W.B. (1992). How in the World Do Students Read? The Hague: International Association for the Evaluation of Educational Achievement.

Elley, W.B. (1994). The IEA Study of Reading Literacy: achievement and instruction in 32 school systems. New York: Pergamon.

Hall-Ellis, S.D. \& Berry, M.A. (1995). School Library Media Centers and Academic Achievement in South Texas. Texas Library Journal, 71(2), 94-7.

HMI Audit Unit. (1996). How good is our school? self-evaluation using performance indicators. SOEID.

Hopkins, D.M. (1989). Elementary School Library Media Programs and the Promotion of Positive Self- Concepts: a report of an exploratory study. The Library Quarterly, 59 (2), 131-147.

Hopkins, D.M., \& Zweizig, D.L. (Eds.). (1999). School Libraries Worldwide, 5(2).

Krashen, S. (1993). The Power of Reading: insights from the research. Englewood, Colorado: Libraries Unlimited, Inc.

Kuhlthau, C.C. (1993). Seeking Meaning: a process approach to library and information services. Norwood, New Jersey: Ablex Publishing Corp.

Kuhlthau, C.C. (ed.) (1994). Assessment and the School Library Media Center. Englewood, CO: Libraries Unlimited, Inc.

Kuhlthau, C.C. (1999). Student Learning in the Library: What Library Power Librarians Say. School Libraries Worldwide, 5(2), 80-96.

Lance, K.C., Welborn, L. \& Hamilton-Pennell, C. (1993). The Impact of School Library Media Centers on Academic Achievement. Castlerock, Colorado: Hi Willow Research and Publishing.

Lance, K.C., Rodney, M.J. \& Hamilton-Pennell, C. (2000a). How School Librarians Help Kids Achieve Standards: the second Colorado study. Colorado: Hi Willow Research and Publishing.

Lance, K.C., Hamilton-Pennell, C. \& Rodney, M.J. (2000b). Information empowered: The School Librarian as an Agent of Academic Achievement in Alaska Schools. Revised edn, Juneau: Alaska State Library.

Lance, K.C., Rodney, M.J. \& Hamilton-Pennell, C. (2000c). Measuring Up to Standards: the impact of school library programs \& information literacy in Pennsylvania schools. Pennsylvania: Pennsylvania Department of Education's Office of Commonwealth Libraries. http://www.statelibrary.state.pa.uk/libraries/lib/libraries/measuringup.pdf. [2001]. 
London's Transport Museum. (2001). The After Schools project 1 year on. London: London's Transport Museum.

Marshall, J. (1993). The impact of information services on decision making: some lessons from the financial and health care sectors. London: British Library Research \& Development Dept. Information policy briefings 1.

Marshall, J.G. (1993). The Impact of the Special Library on Corporate Decision-making. Washington: Special Libraries Association. SLA Research Series 8.

Marshall, J.G. (1992). "The impact of the hospital library on clinical decision making: the Rochester study". Bulletin of the Medical Library Association, 80 (2).

McNicol, S. (1999). Read All About It, the Benefits of Organising a Newspaper Day. The School Librarian, 47 (4), 175-178.

Murray, J. (2000). How School Librarians Can Contribute to the Personal Growth of Students with Disabilities. Orana: Journal of School and Children's Librarianship 36 (2), 5-11.

Oberg, D. (1999). A Library Power Case Study of Lakeside Elementary School, Chattanooga, Tennessee. School Libraries Worldwide, 5 (2), 63-79.

SCCC. (1999). Curriculum Design for the Secondary Stages. Guidelines for Schools. Dundee: Scottish Consultative Council on the Curriculum. http://www.sccc.ac.uk/pdfs/secondary.pdf [15-02-01].

Sharp, C., Kendall, L., Bhabra, S., Schagen, I. \& Duff, J. (2001). Playing for Success: an Evaluation of the Second Year.

Small, R.V. (1998). Designing Motivation into Library and Information Skills Instruction. School Libraries Media Quarterl, 1. http://www.ala.org/aasl/SLMQ/small.html [27/03/01].

Small, R.V. (1999). An Exploration of Motivational Strategies Used by Library Media Specialists During Library and Information Skills Instruction. School Library Media Research Online, 2. http://ala.org/aasl/SLMR/vol2/motive.html [22/11/01].

Smith, E.G. (2001). Texas School Libraries: standards, resources, services, and students' performance. [Texas]: EGS Research \& Consulting for Texas State Library and Archives Commission. http://www.tsl.state.tx.us/ld/pubs/schlibsurvey/index.html [2310-01].

SOEID, SCCC, SLA, \& SLIC. (1999). Taking a (loser Look at the School Library Resource Centre: self-evaluation using performance indicators. SOEID/SCCC/SLA/SLIC. http://www.svtc.org.uk/sccc/closer/library.pdf [17/12/01].

Train, Briony, et al. (2000). The Value and Impact of Homework Clubs in Public Libraries. Boston Spa: The Library and Information Commission. Library and Information Commission Research Report 32. 
Urquhart, C.J. \& Hepworth, J.B. (1995). The Value to Clinical Decision Making of Information Supplied by NHS Library and Information Services. Boston Spa: British Library Research and Development Department.

Williams, D., Coles, L. \& Wavell, C. (2002). Impact of school library services on achievement and learning in primary schools. London: Department for Education and Skills, Resource: The Council for Museums, Archives and Libraries. http://www.resource.gov.uk/information/research/impactslprim.doc

Williams, D. \& Wavell, C. (2001). The Impact of the School Library Resource Centre on Learning. Aberdeen: The Robert Gordon University for Resource: The Council for Museums, Archives and Libraries.

http://www.resource.gov.uk/information/research/respubs2001.asp\#lic112

Williams, D., Wavell, C. \& Coles, L. (2001). Impact of the School Library Services on Achievement and Learning. London: Department for Education and Skills, Resource: The Council for Museums, Archives and Libraries.

http://www.resource.gov.uk/information/research/respubs2001.asp\#impactsl

Zweizig, D.L. \& Hopkins, D.M. (1999). Lessons from Library Power. Enriching Teaching and Learning. An Initiative of the DeWitt Wallace-Reader's Digest Fund. Englewood, Colorado: Libraries Unlimited, Inc. 